\title{
Evolution of ore-forming fluids associated with late Hercynian antimony deposits in Central/Western Spain: case study of Mari Rosa and El Juncalón
}

\author{
LORENA ORTEGA and ELENA VINDEL
}

\author{
Dpto. Cristalografía y Mineralogía, Universidad Complutense, 28040 - Madrid, Spain
}

\begin{abstract}
Located in Central-Western Spain, the late Hercynian Mari Rosa and El Juncalón vein-type antimony deposits are hosted by Late Precambrian metasedimentary rocks and are spatially related to Late Carboniferous/Early Permian granitoids. At Mari Rosa, the following hydrothermal stages are recognized: 1) arsenopyrite-(pyrite), 2) stibnite-gold and 3) pyrite-(pyrrhotite-galena-sphalerite-chalcopyrite-tetrahedrite-boulangerite-berthierite-stibniteullmannite-cobaltite). Only the second stage is of economic importance, containing massive stibnite. El Juncalón is characterized by a simple mineral paragenesis composed of stibnite with very minor pyrite. Gold is associated with stibnite, which contains up to $30 \mathrm{ppm}$ Au at Mari Rosa and up to $0.4 \mathrm{ppm} \mathrm{Au}$ at El Juncalón.

Fluids associated with ore deposition lie in the $\mathrm{H}_{2} \mathrm{O}-\mathrm{NaCl}-\mathrm{CO}_{2}-\mathrm{CH}_{4}-\mathrm{N}_{2}$ system, but $\mathrm{CO}_{2}$ is absent in the El Juncalón mineralized rocks. The fluids cooled progressively, from initial circulation temperatures close to $400^{\circ} \mathrm{C}$ in the early stages to temperatures of approximately $150^{\circ} \mathrm{C}$ in the late episodes. The fluid composition evolution is also characterized by a progressive increase in the overall water content of the fluids and by an increase in the relative proportions of $\mathrm{N}_{2}$ with respect to $\mathrm{CH}_{4}$ and $\mathrm{CO}_{2}$ in the volatile fraction. At Mari Rosa, massive stibnite deposition resulted from a boiling process at $300^{\circ} \mathrm{C}$ and $0.9-1 \mathrm{kbar}$. Unmixing of the fluid was induced by sudden pressure drops associated with dilational jogs during low-angle fault movements. Cooling of the fluid is recognized as the driving mechanism for stibnite deposition at $250^{\circ}-270^{\circ} \mathrm{C}$ and $50-300$ bars at El Juncalón.
\end{abstract}

Key-words: Spain, late Hercynian, fluid inclusions, antimony, boiling, PT conditions.

\section{Introduction}

Widespread plutonic activity in Central Iberia during late Hercynian times resulted in a series of $\mathrm{U}, \mathrm{P}, \mathrm{Li}, \mathrm{Sn}-\mathrm{W}, \mathrm{Sb}$ and $\mathrm{Pb}-\mathrm{Zn}$ mineralizations within and around granitic massifs. The Alburquerque and Entre-os-Ríos batholiths in Spain and Portugal respectively are examples of granitic occurrences in the Central Iberian Zone (CIZ) which contain spatially related $\mathrm{Sb}-(\mathrm{Au})$ deposits (Fig. 1) (Portugal et al., 1971; Gumiel et al., 1976; Gumiel \& Arribas, 1987; Couto et al., 1990). Even though comprehensive geological and mineralogical studies were carried out on the Iberian $\mathrm{Sb}$ mineralizations during the late 1970's and early 1980's (Gumiel, 1983; Gumiel $\&$ Arribas, 1987), no data regarding the ore fluid composition or evolution were available until recently (Ortega et al., 1991 a, b; Ortega, 1993).

Among the Spanish Sb deposits, Mari Rosa and El Juncalón, which are $200 \mathrm{~km}$ apart (Fig. 1), display similar but also contrasting features. These deposits crop out within the cores of Hercynian anticlines and are spatially related to late Hercynian granitic intrusions: Mari Rosa is located $8 \mathrm{~km}$ north of the Alburquerque batholith and El Juncalón lies above hidden granitic bodies. Host rocks are metasedimentary rocks of Late Precambrian age. Major differences between both deposits are clear in terms of the type of structures hosting the mineralization: 1) minor low-angle reverse faults and older subvertical pinch-and-swell recrystallized metamorphic structures in Mari Rosa, and 2) strike-slip faults 

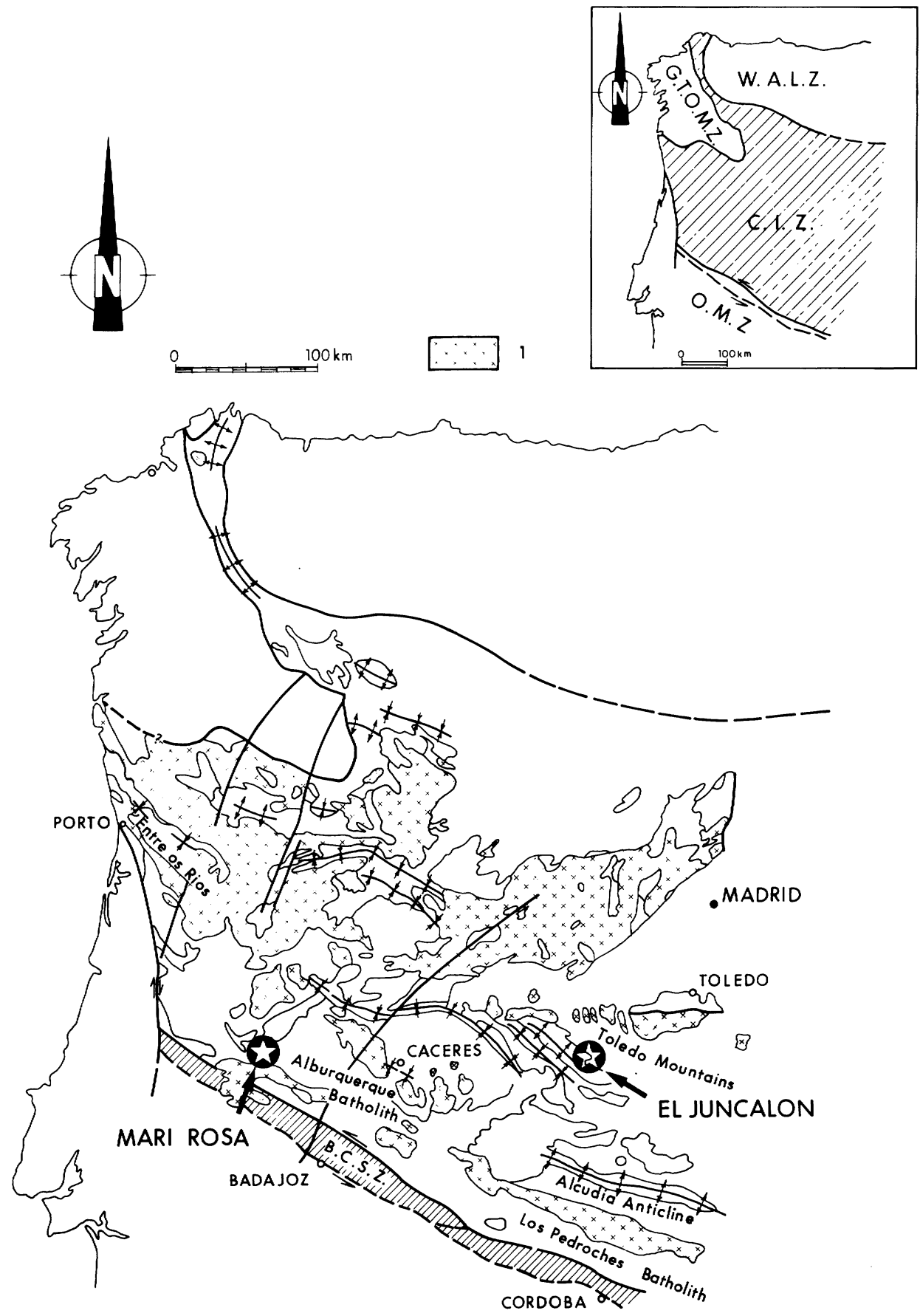

Fig. 1. Location map showing the Mari Rosa and El Juncalón antimony deposits within the Central Iberian Zone, Iberian Hercynian Massif. Only granitic outcrops (1) and major Hercynian folds within the Central Iberian Zone are shown. W.A.L.Z.: West Asturian-Leonese Zone; G.T.O.M.Z.: Galician Tras Os Montes Zone; C.I.Z.: Central Iberian Zone; B.C.S.Z.: Badajoz-Córdoba Shear Zone; O.M.Z.: Ossa Morena Zone. After Díez Balda et al. (1990). 
in the case of El Juncalón. The degree of complexity of the mineral parageneses is also very different: while a very simple assemblage characterizes El Juncalón (stibnite-gold-pyrite), a complex assemblage is observed at Mari Rosa (stibnite, gold, multiple sulphides and $\mathrm{Pb}, \mathrm{Cu}, \mathrm{Fe}$, $\mathrm{Ni}$ and Co sulphosalts). The stibnite ore textures are also remarkably different, ranging from massive in Mari Rosa to scattered and discrete at El Juncalón. These contrasting features make the deposits ideal for a comparison in order to obtain a better understanding of antimony ore-forming processes in Central Iberia.

\section{General geology}

The Mari Rosa and El Juncalón Sb mineralizations are hosted by monotonous metasedimentary sequences (metagreywackes, phyllites and slates) belonging to the so-called Schist Greywacke Complex (Late Precambrian), a synorogenic flyschoid unit (Bascones \& Mart1n Herrero, 1982; Quesada et al., 1987). This unit underwent deformation during the Cadomian and Hercynian orogenies, and shows three deformational episodes: F1 (620-550 Ma; Cadomian), F2 (370-330 Ma; Hercynian) and F3 (Lower/Middle Carboniferous; Hercynian). The F1 episode has a relic character and can only be observed at the microscopic scale $\left(\mathrm{S}_{1}\right)$. The F2 episode led to similar folds with subvertical axial planes and associated penetrative cleavage $\left(\mathrm{S}_{2}\right)$. To the south of the study area, the F2 deformation gave rise to the Badajoz-Cordoba Shear Zone, a NW-SE major mylonitic corridor separating the Central Iberian and the Ossa Morena Zones of the Hesperian Massif (Fig. 1). The F3 episode overprinted the F2 structures and gave rise to a nonpenetrative crenulation cleavage $\left(\mathrm{S}_{3}\right)$. The late Hercynian event is characterized by general extensional regime leading to major intrusions of granitoids (Doblas et al., 1994). Coeval local compressional structures, such as minor reverse faults hosting antimony mineralization, can be also recognized within the area. These faults are clearly post-Hercynian as they cross-cut the previous cleavages. Regional metamorphism during the Hercynian orogeny (F2) resulted in greenschist facies assemblages characterized by chlorite-(biotite)-muscovitequartz.

Some $8 \mathrm{~km}$ to the south of Mari Rosa, outcrops of the Alburquerque batholith dominate the re- gional geological framework. These granitoids were intruded in late Hercynian times (Permian, Rb/Sr: $286 \pm 3.6 \mathrm{Ma}$, Roberts et al., 1991) and consist of peraluminous calc-alkaline, S-type granites with high contents of $\mathrm{Na}_{2} \mathrm{O}, \mathrm{K}_{2} \mathrm{O}$ and $\mathrm{P}_{2} \mathrm{O}_{5}$ (Gallego \& Gumiel, 1993). Their emplacement took place under extensional conditions after the Hercynian folding. The intrusions generated major metamorphic aureoles consisting of hornblende and albite-epidote hornfels facies rocks. No granitoid outcrops are recognized within the El Juncalón area, but a comprehensive drilling, geophysical and geochemical survey carried out by the ITGE during the 1980's has shown the existence of concealed granitoid masses. These granitoids can be ascribed to the same type and age as those of the Alburquerque Batholith (ITGE, 1993).

\section{Structure and mineralization}

\section{Mari Rosa}

Given the complex structural and hydrothermal history of Mari Rosa, the early vein terminology (Ortega et al., 1991a, b) was revised and replaced by a new one based on simple geometric relationships. Thus, two types of veins can be defined: $\mathrm{Vp}$ and $\mathrm{Vo}$, i.e. veins respectively parallel and oblique to the $S_{2}$ cleavage. Vp veins show pinchand-swell structures, contain minor mineralization and strike $\mathrm{N} 120^{\circ}-130^{\circ} / 80^{\circ} \mathrm{SW}$. These veins are early metamorphic segregations formed during F2. The hydrothermal mineral deposition, however, corresponds to a later event (late Hercynian) involving reopening, quartz recrystallization and precipitation of a complex mineral paragenesis. Vo veins are small bodies of massive stibnite hosted within dilational jogs occurring along low-angle reverse faults striking N-S to $\mathrm{N} 20^{\circ} / 10^{\circ}-30^{\circ} \mathrm{E}$. They are clearly post-Hercynian as they crosscut the structures developed during the $\mathbf{F} 2$ and $\mathbf{F 3}$ compressions. A recent tectonic synthesis of the Central Iberian domain reveals the existence of local compressional regimes during the overall extensional collapse of the Hercynian orogen (Doblas et al., 1994). Thus, the existence of minor reverse faults may be regarded as a local feature rather than as a marker of the Hercynian compressions. Based on these criteria, the $\mathrm{Vp}$ and Vo hydrothermal vein infillings are considered to be late Hercynian.

The mineralization developed during three hy- 


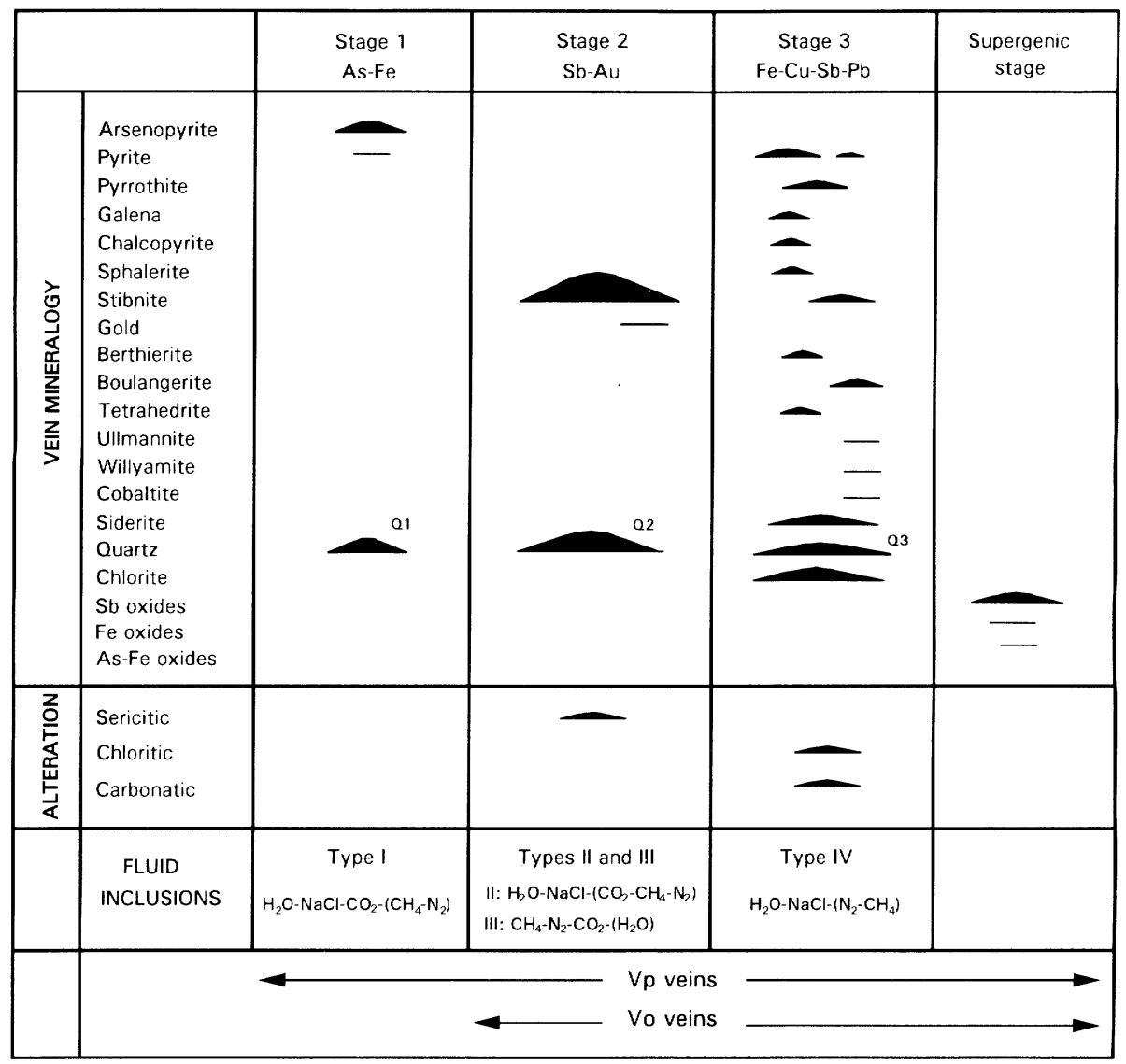

Fig. 2. Mineral paragenesis, alteration and fluid inclusions in the Mari Rosa deposit.

drothermal stages (Fig. 2): 1) arsenopyrite(pyrite)-quartz $\left(\mathrm{Q}_{1}\right), 2$ ) stibnite-gold-quartz $\left(\mathrm{Q}_{2}\right)$, and 3) pyrite-(pyrrhotite-galena-sphaleritechalcopyrite-tetrahedrite-boulangerite-berthieritestibnite-ullmannite-cobaltite)-quartz $\left(\mathrm{Q}_{3}\right)$. The stage 1 mineral assemblage is only observed in $\mathrm{Vp}$ veins. The most noteworthing textural feature is the second-stage stibnite, which is a massive ore, with local intergrowths of native gold (up to $30 \mathrm{ppm} \mathrm{Au}$; Ortega, 1993). Quartz displays a high textural variability in all three hydrothermal stages. Vp veins contain early stretched metamorphic quartz $\left(\mathrm{Q}_{\mathrm{M}}\right)$ almost totally recrystallized into hydrothermal quartz $\left(\mathrm{Q}_{1}-\mathrm{Q}_{3}\right) . \mathrm{Q}_{1}$ is clear and occurs as relic cores surrounded by coarse-grained quartz $\left(\mathrm{Q}_{2}\right)$ in $\mathrm{Vp}$ veins. Dilational phenomena in $V_{0}$ veins have enabled the formation of well-developed $\mathrm{Q}_{2}$ euhedral quartz crystals. $\mathrm{Q}_{3}$ is a finely crystalline quartz occur- ring in both $\mathrm{Vp}$ and $\mathrm{Vo}$ veins along $\mathrm{Q}_{2}$ crystal boundaries.

Mineral deposition was accompanied by weak hydrothermal alteration which does not extend more than a few centimetres beyond the vein contacts. The main stage of stibnite deposition is associated with sericitization, which is clearly marked by a sharp increase in the $\mathrm{K}_{2} \mathrm{O} / \mathrm{Na}_{2} \mathrm{O}$ ratio near the veins. Chlorite and carbonates formed during the late stage.

\section{El Juncalón}

Although three stages of mineral deposition are recognized at El Juncalón, the mineralization here has a rather different structural and hydrothermal history than at Mari Rosa. El Juncalón is structurally controlled by a wrench fault, striking $\mathrm{N} 110^{\circ}-130^{\circ} / 85^{\circ} \mathrm{W}$ for over $1 \mathrm{~km}$, which 


\begin{tabular}{|c|c|c|c|c|}
\hline & $\begin{array}{c}\text { Stage } 1 \\
\mathrm{Fe}\end{array}$ & $\begin{array}{l}\text { Stage } 2 \\
\text { Sb-(Au) }\end{array}$ & $\begin{array}{l}\text { Stage } 3 \\
\text { Barren }\end{array}$ & $\begin{array}{c}\text { Supergenic } \\
\text { stage }\end{array}$ \\
\hline \multicolumn{5}{|l|}{ MINERALOGY } \\
\hline \multicolumn{5}{|l|}{ Pyrite } \\
\hline \multicolumn{5}{|l|}{ Stibnite } \\
\hline \multicolumn{5}{|l|}{ Quartz } \\
\hline \multirow{2}{*}{\multicolumn{5}{|c|}{$\begin{array}{l}\text { Sb oxides } \\
\text { Fe oxides }\end{array}$}} \\
\hline & & & & \\
\hline \multicolumn{5}{|l|}{ ALTERATION } \\
\hline \multicolumn{5}{|l|}{ Argillic } \\
\hline \multicolumn{5}{|l|}{ Sericitic } \\
\hline \multicolumn{5}{|l|}{ Chloritic } \\
\hline FLUID & Type A, B* $E^{*}$ & Type C & Type D & \\
\hline INCLUSIONS & $\mathrm{H}_{2} \mathrm{O}-\mathrm{NaCl}-\mathrm{CH}_{4}$ & $\mathrm{H}_{2} \mathrm{O}-\mathrm{NaCl}-\left(\mathrm{CH}_{4}-\mathrm{N}_{2}\right)$ & $\mathrm{H}_{2} \mathrm{O}-\mathrm{NaCl}$ & \\
\hline
\end{tabular}

Fig. 3. Mineral paragenesis, alteration and fluid inclusion in the El Juncalón deposit. * Type B and E inclusions result from post-trapping modifications of some type $\mathrm{A}$ inclusions during brecciation (see text).

cuts across the Hercynian structures. The mineralization is hosted by the fault rock and by hydrothermally-altered tectonic breccias running parallel to the main structure. The fault-hosted mineralization occurs as lensoid-shaped bodies of quartz and stibnite. In contrast to Mari Rosa, quartz accounts for most of the vein filling, with only discrete nests of radiating acicular stibnite

Table 1. Summary of microthermometric and Raman data for Mari Rosa quartz veins.

\begin{tabular}{|c|c|c|c|c|}
\hline \multirow[b]{2}{*}{$\mathbf{V v} / \mathbf{V t}$} & Type I & Type II & Type III & Type IV \\
\hline & $0.4-0.6$ & $0.15-0.25$ & $>0.9$ & 0.1 \\
\hline \multicolumn{5}{|c|}{ Microthermometric data $\left({ }^{\circ} \mathrm{C}\right)$} \\
\hline Th $\mathrm{CH}_{4}-\mathrm{N}_{2}$ & - & - & $\begin{array}{c}-138^{\circ} \text { to }-121^{\circ} \mathrm{C} \\
(\mathrm{L}, \mathrm{V} \text { or } \mathrm{C})\end{array}$ & - \\
\hline $\mathrm{Tm} \mathrm{CO}_{2}$ & -73.5 to $-61^{\circ} \mathrm{C}$ & - & $-77.2^{\circ}$ to $-66^{\circ} \mathrm{C}$ & - \\
\hline $\mathrm{Th} \mathrm{CO}_{2}$ & -45 to $-19^{\circ} \mathrm{C}(\mathrm{V})$ & - & - & - \\
\hline Tm ice & - & $-6^{\circ}$ to $-2^{\circ} \mathrm{C}$ & - & $-5.2^{\circ}$ to $-1.5^{\circ} \mathrm{C}$ \\
\hline $\mathrm{Tm} \mathrm{Cl}$ & $9.5^{\circ}$ to $14.5^{\circ} \mathrm{C}$ & $5^{\circ}$ to $8^{\circ} \mathrm{C}$ & - & - \\
\hline THI & $275^{\circ}$ to $377^{\circ} \mathrm{C}$ & $190^{\circ}$ to $330^{\circ} \mathrm{C}$ & - & $160^{\circ}$ to $266^{\circ} \mathrm{C}$ \\
\hline $\begin{array}{l}\text { Salinity } \\
\text { (\% eq NaCl) }\end{array}$ & - & 3 to $9 \% *$ & - & 2.5 to $9 \%$ \\
\hline \multicolumn{5}{|c|}{ Composition of vapour phase (Raman data) } \\
\hline & $\begin{array}{r}\mathrm{XCO}_{2}: 0.61-0.34 \\
\mathrm{XCH}_{4}: 0.43-0.29 \\
\mathrm{XN}_{2}: 0.23-0.10\end{array}$ & $\begin{array}{r}\mathrm{XCO}_{2}: 0.41-0.29 \\
\mathrm{XCH}_{4}: 0.23-0.06 \\
\mathrm{XN}_{2}: 0.60-0.43\end{array}$ & $\begin{array}{r}\mathrm{XCO}_{2}: 0.21-0.14 \\
\mathrm{XCH}_{4}: 0.28-0.16 \\
\mathrm{XN}_{2}: 0.56-0.64\end{array}$ & $\begin{aligned} \mathrm{XCO}_{2}: & \text { n.d. } \\
\mathrm{XCH}_{4}: & 0.24-0.23 \\
\mathrm{XN}_{2}: & 0.77-0.76\end{aligned}$ \\
\hline
\end{tabular}

* Salinity maximum values, estimated from Tm ice in presence of clathrate. X in molar fractions. n.d.: not detected. Tm Cl: clathrate melting temperaure; Th: homogenization temperature of the non-aqueous fraction; TH: total homogenization temperature in water-bearing inclusions. 
Table 2. Composition, molar volume and density for type III inclusions, considering $0 \%$ and $7 \%$ (vol.) $\mathrm{H}_{2} \mathrm{O}$ content.

\begin{tabular}{|lccccccc|}
\hline $\mathbf{I F}$ & 2MR46 & 2MR50 & 2MR116 & 2MR117 & MR66 & MR70 & MR184 \\
\hline $\mathbf{0 \%}$ (vol.) $\mathbf{H}_{\mathbf{2}} \mathbf{O}$ & & & & & & & \\
$\mathbf{X C O}_{2}$ & 0.17 & 0.14 & 0.21 & 0.21 & 0.21 & 0.195 & 0.18 \\
$\mathbf{X C H}_{4}$ & 0.26 & 0.28 & 0.22 & 0.23 & 0.18 & 0.165 & 0.18 \\
$\mathbf{X N}_{2}$ & 0.57 & 0.58 & 0.57 & 0.56 & 0.61 & 0.64 & 0.64 \\
\hline $\mathbf{T h}$ & $-124.8 \mathrm{~L}$ & $-125.3 \mathrm{~L}$ & $-120.4 \mathrm{~V}$ & $-121.1 \mathrm{~V}$ & $-128.4 \mathrm{~V}$ & $-129.6 \mathrm{~V}$ & $-131.1 \mathrm{~V}$ \\
\hline $\mathbf{X v}$ & 0.83 & 0.86 & 0.79 & 0.79 & 0.79 & 0.805 & 0.82 \\
$\overline{\mathbf{V}} \mathbf{v}$ & 70 & 66 & 100 & 100 & 105 & 105 & 120 \\
$\mathbf{X s}$ & 0.17 & 0.14 & 0.21 & 0.21 & 0.21 & 0.195 & 0.18 \\
$\overline{\mathbf{V}}_{\mathbf{s}}$ & 28.2 & 28.2 & 28.2 & 28.2 & 28.2 & 28.2 & 28.2 \\
\hline$\overline{\mathbf{V}}_{\mathbf{t}}$ & 62.9 & 60.7 & 84.9 & 84.9 & 88.9 & 90.0 & 103.5 \\
$\mathbf{d t}$ & 0.44 & 0.44 & 0.34 & 0.34 & 0.33 & 0.32 & 0.28 \\
\hline $\mathbf{7 \%}$ (vol.) $\mathbf{H}_{2} \mathbf{O}$ & & & & & & \\
$\mathbf{X C O}$ & 0.13 & 0.11 & 0.155 & 0.155 & 0.15 & 0.14 & 0.30 \\
$\mathbf{X C H}$ & 0.21 & 0.225 & 0.16 & 0.17 & 0.13 & 0.12 & 0.125 \\
$\mathbf{X N}$ & 0.45 & 0.46 & 0.425 & 0.415 & 0.45 & 0.46 & 0.125 \\
$\mathbf{X} H_{2}$ & 0.21 & 0.205 & 0.26 & 0.26 & 0.27 & 0.28 & 0.45 \\
$\mathbf{O}$ & & & & & & & \\
\hline $\mathbf{d t}$ & 0.48 & 0.48 & 0.39 & 0.39 & 0.38 & 0.37 & 0.33 \\
$\overline{\mathbf{V}}_{\mathbf{t}}$ & 53.5 & 51.9 & 67.5 & 67.5 & 70.55 & 69.8 & 77.85 \\
\hline
\end{tabular}

$\mathrm{X}$ for $0 \% \mathrm{H}_{2} \mathrm{O}$ from Raman analysis; $\overline{\mathrm{V}}_{\mathrm{v}}$ values obtained from the TX diagram of the $\mathrm{CH}_{4}-\mathrm{N}_{2}$ binary system (van den Kerkhof, 1988). Calculation procedure from Ramboz et al. (1985). X: molar fractions, $\overline{\mathrm{V}}: \mathrm{cm}^{3} / \mathrm{mol}, \mathrm{d}: \mathrm{g} / \mathrm{cm}^{3}$. $\mathrm{Xv}_{\mathrm{v}}$ and $\overline{\mathrm{V}}_{\mathrm{v}}$ : molar fractions and molar volume of the volatile fraction; Xs and Vs: molar fractions and molar volume of the solid $\mathrm{CO}_{2} ; \mathbf{V t}$ : total molar volume; dt: total density.

crystals. Stibnite in the tectonic breccias occurs as veinlets cross-cutting both fragments and matrix. Of the three hydrothermal stages, only the second resulted in stibnite deposition, the first one depositing minor pyrite and quartz, while minor barren quartz was formed in the last stage (Fig. 3). Gold has not been detected optically in the studied samples, but chemical analyses of the ore reveal a mean value of $0.4 \mathrm{ppm}$ (Gumiel \& Arribas, 1987). Quartz occurs as polygonal aggregates of crystals (stage 2) with relic brecciated cores (stage 1). Hydrothermal alteration evolved from a strong argillic-sericitic alteration in the first stage towards milder conditions in the second (minor sericite and chlorite). No alteration mineral assemblages are recognized in the third stage. Brecciation between stages 1 and 2 created the adequate conditions for major fluid circulation which ultimately gave rise to deposition of stibnite during the peak of stage 2 . This brecciation episode can be clearly bracketed in time since the breccia clasts include highly altered (argillic-sericitic assenblage: stage 1) rock fragments.

\section{Fluid inclusions}

Fluid-inclusion studies were carried out on quartz from the Mari Rosa and El Juncalón mineralized veins. Microthermometric analyses were performed using a Chaixmeca stage (Poty et al., 1976), calibrated at low temperatures with $\mathrm{CO}_{2}$ fluid inclusions and toluene standards. Volatiles composition was determined in selected inclusions by Raman microspectrometry on a JobinYvon U-1000 (BRGM, Orléans) and on Dilor Microdil-28 (Free University, Amsterdam) 
Table 3. Summary of microthermometric and Raman data for El Juncalón.

\begin{tabular}{|c|c|c|c|c|c|c|c|}
\hline & \multicolumn{3}{|c|}{ Type A } & \multirow[t]{2}{*}{ Type B } & \multirow[t]{2}{*}{ Type C } & \multirow[t]{2}{*}{ Type D } & \multirow[t]{2}{*}{ Type E } \\
\hline & $\mathbf{A}_{1}$ & $\mathbf{A}_{2}$ & $\mathbf{A}_{3}$ & & & & \\
\hline $\mathbf{V v} / \mathbf{V t}$ & $0.5-0.8$ & $0.3-0.5$ & $0.2-0.3$ & $0.3-0.5$ & $0.1-0.2$ & $<0.1$ & $>0.9$ \\
\hline \multicolumn{8}{|c|}{ Microthermometric data $\left({ }^{\circ} \mathrm{C}\right)$} \\
\hline Tm ice & $-2.9 \mathrm{t}$ & -0.2 & -2.4 to -0.7 & -2.5 to -1.3 & -2.8 to -0.8 & $\begin{array}{c}-2.1 \text { to }- \\
0.5\end{array}$ & - \\
\hline Tн & $300 \mathrm{t}$ & 380 & 285 to 350 & 345 to 385 & 207 to 295 & $\begin{array}{c}164 \text { to } \\
218 \\
\end{array}$ & - \\
\hline $\begin{array}{l}\text { Salinity } \\
(\% \mathrm{NaCl})\end{array}$ & $0.5 \mathrm{t}$ & 4.8 & 1.3 to 4 & 2.3 to 4.2 & 1.4 to 4.6 & 0.8 to 3.5 & - \\
\hline \multicolumn{8}{|c|}{ Composition of vapour phase (Raman data) } \\
\hline & \multicolumn{3}{|c|}{$\mathrm{CH}_{4}$} & n.d. & $\begin{array}{r}\mathrm{XN}_{2}: 0.66-0.50 \\
\mathrm{XCH}_{4}: 0.50-0.44\end{array}$ & n.d. & $\mathrm{CH}_{4}$ \\
\hline
\end{tabular}

X: molar fractions; n.d.: not detected; Tm: melting temperature; TH: total homogenization temperature.

Raman microprobes. Fluid-inclusion data are summarized in Tables 1, 2 (Mari Rosa) and 3 (El Juncalón).

\section{Mari Rosa}

\section{Inclusion types}

Four types of fluid inclusions were observed within the quartz veins. Type I, II and IV correspond to biphase water-bearing inclusions (Vapour volume/total volume, $\mathrm{Vv} / \mathrm{Vt}=0.4-0.6$, $0.15-0.2$ and $<0.1$, respectively), while type III typically appears as monophase vapour inclusions at room temperature. The volatile composition belongs to the system $\mathrm{CO}_{2}-\mathrm{CH}_{4}-\mathrm{N}_{2}$, ranging from $\mathrm{CO}_{2}$-rich (type I) to $\mathrm{N}_{2}$-rich (type IV) mixtures.

The relative chronology of the inclusions is well established. Type I occurs as isolated inclusions in clear cores of quartz crystals $\left(Q_{1}\right)$. They are the earliest inclusions in the hydrothermal history of the deposit, predating the Vo veins formation since they only occur in $\mathrm{Vp}$ veins. By contrast, the remaining types (II, III and IV) are observed in both Vp and Vo veins.

Type II and III are primary inclusions in $\mathrm{Vo}_{0}$ veins which were trapped contemporaneously; both types II and III are seen to delimit the growth faces of idiomorphic quartz $\left(\mathrm{Q}_{2}\right)$, either sharing the same planar arrays or within separated parallel alignements (Fig. 4 a, b). This distribution indicates the existence of a hetero- geneous fluid during trapping (Roedder, 1984). Small grains of stibnite were observed along the growth faces of idiomorphic quartz, indicating a close relationship between type II/III inclusions and the mineralization. Other common occurrences correspond to groups of abundant type II inclusions (with some type III) and planar arrangements of type III inclusions. Occasionally, water-bearing type III-like inclusions (Fig. 4 c) also appear in the same zones as the other types. In Vp veins, both type II and type III inclusions are secondary and occur in clusters or along fractures, postdating the type I inclusions.

Finally, type IV inclusions usually occur as secondary inclusions in healed fractures in both $\mathrm{Vp}$ and $\mathrm{V}_{\mathrm{o}}$ veins, cross-cutting both $\mathrm{Q}_{1}(\mathrm{Vp}$ veins) and $\mathrm{Q}_{2}$ quartz. They are also scattered in the late $\mathrm{Q}_{3}$ microcrystalline quartz.

\section{Fluid inclusion data}

Type I inclusions are two-phase at room temperature with a degree of filling $(\mathrm{Vv} / \mathrm{Vt})$ of around $0.4-0.6 \%$. They have $\mathrm{Tm} \mathrm{CO}_{2}$ between -73.5 and $-61{ }^{\circ} \mathrm{C}$ which is well below the triple point of pure $\mathrm{CO}_{2}\left(-56.6^{\circ} \mathrm{C}\right)$, due to the presence of $\mathrm{CH}_{4}$ and $\mathrm{N}_{2}$. $\mathrm{Th}^{1} \mathrm{CO}_{2}$ fall within a wide range

1 Th: homogenization temperature of the non-aqueous fraction; TH: total homogenization temperature in water-bearing inclusions. 

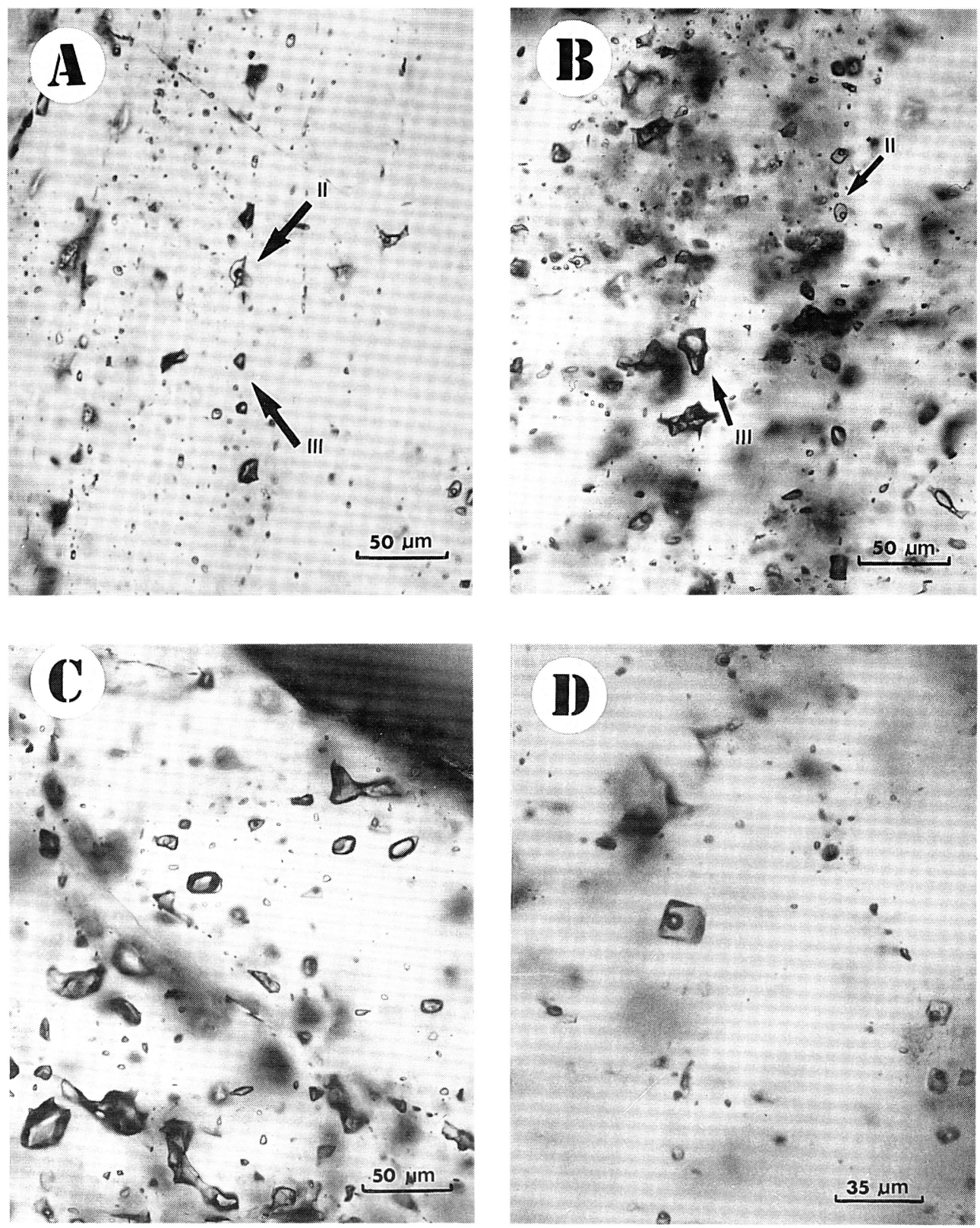

Fig. 4. Mari Rosa: A. Type II and type III inclusions scattered along the same alignement, parallel to a quartz growth face. B. Type II and type III inclusions occurring within adjacent growth faces in idiomorphic quartz. C. Water-bearing type III-like inclusions which represent the mechanical trapping of both $\mathrm{L}$ and $\mathrm{V}$ phases resulting from boiling. El Juncalón: D. Isolated type C inclusions corresponding to the second hydrothermal stage.

between -45 to $-19^{\circ} \mathrm{C}(\mathrm{V})$. The temperature at which this phase transition takes place is significatively affected by the formation of a $\mathrm{CO}_{2}$-rich clathrate, resulting in a strong enrichment of $\mathrm{CH}_{4}$ and $\mathrm{N}_{2}$ in the non-aqueous part of type I inclusions, hence yielding values of $\mathrm{Th} \mathrm{CO}_{2}$ that are 
lower than expected. However, the difficulty of holding low temperatures for long enough with our equipment to achieve clathrate equilibration has also to be taken in account. Ice melting is difficult to measure accurately because of bubble size and clathration; observed values range from -8.4 to $-3.8^{\circ} \mathrm{C}$. Clathrate melting temperatures range from $9.5^{\circ}$ to $14.5^{\circ} \mathrm{C}$. Total homogenization $\left(\mathrm{TH}^{1}\right)$ occurs between $275^{\circ}$ and $377^{\circ} \mathrm{C}$ (Fig. 5), generally into the liquid and sometimes shoeing critical behaviour.

Calculations of molar volume for intermediate compositions in the $\mathrm{CO}_{2}-\mathrm{CH}_{4}-\mathrm{N}_{2}$ system are not possible with the available $\overline{\mathrm{X}}$ diagrams. However, in certain cases these values can be estimated from the appropriate binary subsystems by calculating pseudo-compositions (Ramboz et al., 1985; Thiéry et al., 1994). For type I inclusions, severe restrictions to the molar volume calculation in the $\mathrm{CO}_{2}-\mathrm{CH}_{4}$ system arise from inconsistencies between $\mathrm{Th} \mathrm{CO}_{2}$ and Raman data at room temperature since compositions do not intersect (or do so at unrealistic values) with the homogenization isotherms in the $\mathrm{CO}_{2}-\mathrm{CH}_{4}$ system (van den Kerkhof, 1988; Thiéry et al., 1994). This behaviour may be due either to: 1) the clathrate present at $\mathrm{Th} \mathrm{CO}_{2}$, and/or 2) the approximation of type I volatile composition to a binary system $\left(\mathrm{CO}_{2}-\mathrm{CH}_{4}\right)$ is not correct in this case, given the high molar fractions of the third volatile component (up to $0.23 \mathrm{~N}_{2}$ ). Therefore, the determination of molar volumes from microthermometric data is not possible in these inclusions.

Type II inclusions are, together with type III, the most abundant in all samples. The former are biphase at room temperature and have a relatively constant degree of filling $(\mathrm{Vv} / \mathrm{Vt})$ between 0.15-0.25\% (Fig. 4 a, b). These inclusions show complex microthermometric behaviour. On cooling, the observed phase transitions involve the nucleation of ice in the aqueous fraction and the simultaneous nucleation of a solid phase, interpreted as a complex clathrate (Ortega et al., 1991b), within the non-aqueous part of the inclusion. In spite of the presence of volatiles such as $\mathrm{CO}_{2}, \mathrm{CH}_{4}$ and $\mathrm{N}_{2}$, no further phase transitions were observed in these inclusions on cooling down to $-170^{\circ} \mathrm{C}$. The clathrate became invisible a few degrees below $\mathrm{Tm}$ ice i.e. $-6^{\circ}$ to $-2^{\circ} \mathrm{C}$. Following a cyclic multistage cooling model (Collins, 1979), the final dissociation temperature for this clathrate is estimated to be within the range $5^{\circ} \mathrm{C}-8^{\circ} \mathrm{C}$. Total homogenization took place between 190 to $330^{\circ} \mathrm{C}$ (L) (Fig. 5). However, decrepitation prior to final homogenization was also very common in these inclusions, ranging from $230^{\circ}$ to $310^{\circ} \mathrm{C}$ (Fig. 5). This behaviour, observed in inclusions larger than $15 \mu \mathrm{m}$, indicates an internal pressure at decrepitation of 0.9-1 kbar (Leroy, 1979; Bodnar et al., 1989), which correspond to minimum trapping pressures.

Both the presence of complex clathrates and the absence of phase transitions at low temperatures prevent any calculation of molar volume for type II inclusions. Clathrates also affect salinity estimations, although maximum values of salinity between 3 and $9 \%$ eq. $\mathrm{NaCl}$ can be obtained from $\mathrm{Tm}$ ice.

Type III inclusions appear to be monophase at room temperature (Fig. 4 a, b, c), although the existence of small amounts of water $(<10 \%$ in volume) cannot be ruled out. Below $-110^{\circ} \mathrm{C}$, $\mathrm{N}_{2}-\mathrm{CH}_{4}$ liquid and vapour phases coexist with solid $\mathrm{CO}_{2}$. Temperatures of homogenization range from $-138^{\circ}$ to $-121^{\circ} \mathrm{C}$ ( $\mathrm{L}, \mathrm{V}$ or near critical), while solid $\mathrm{CO}_{2}$ sublimates between $-77.2^{\circ}$ and $-66^{\circ} \mathrm{C}$. Partial molar volume calculations can be made from $\mathrm{Th} \mathrm{CH}_{4}-\mathrm{N}_{2}$ and Raman data in the system $\mathrm{N}_{2}-\mathrm{CH}_{4}$ (van den Kerkhof, 1988; Table 2), with the assumption that all $\mathrm{CO}_{2}$ is partitioned into the solid phase at this temperature. Total molar volume is obtained by applying a correction which corresponds to molar volume of solid $\mathrm{CO}_{2}\left(\overline{\mathrm{V}}=28.2 \mathrm{~cm}^{3} \cdot \mathrm{mol}^{-1}\right)$. Total molar volumes for selected type III inclusions range from 60.7 to $62.9 \mathrm{~cm}^{3}$. $\mathrm{mol}^{-1}$ for those homogenizing into $\mathrm{L}$, and from 84.9 to $103.5 \mathrm{~cm}^{3} \cdot \mathrm{mol}^{-1}$ for those homogenizing into $\mathrm{V}$ near critical conditions. These values are lower if minor amounts of water are considered. For example, maximun values of $70.15 \mathrm{~cm}^{3} \cdot \mathrm{mol}^{-1}$ can be obtained for inclusions homogenizing in $\mathrm{V}$ with $10 \% \mathrm{vol}$ $\mathrm{H}_{2} \mathrm{O}$.

Occasionally, type III-like inclusions with an aqueous liquid phase $(<30 \% \mathrm{vol})$ were observed (Fig. 4 c.). Their microthermometric behaviour at very low temperatures is similar to that of type III inclusions. Other phase transitions observed in these inclusions correspond to the melting of a gas hydrate between $9^{\circ}$ and $15^{\circ} \mathrm{C}$, with total homogenization into vapour between $340^{\circ}$ and $385^{\circ} \mathrm{C}$. This group of inclusions is very rare compared to the typical monophase type III inclusions.

Type IV consists of small $(<10 \mu \mathrm{m})$ biphase inclusions, with a degree of filling $(\mathrm{Vv} / \mathrm{Vt})$ of up to 0.1 . The non-aqueous part is composed of $\mathrm{N}_{2}$ 


\section{EL JUNCALON}

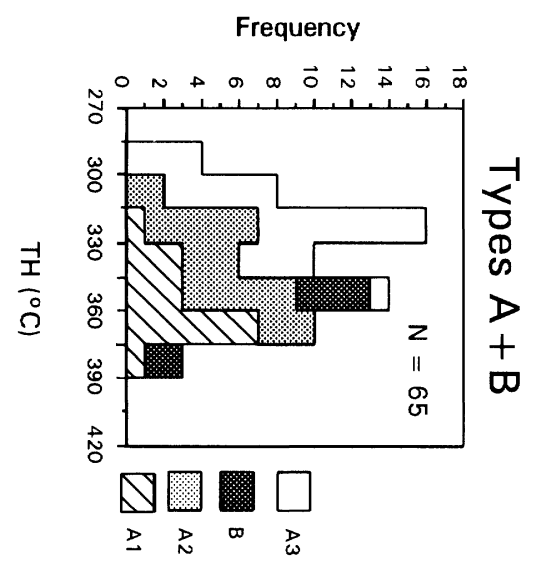

Frequency

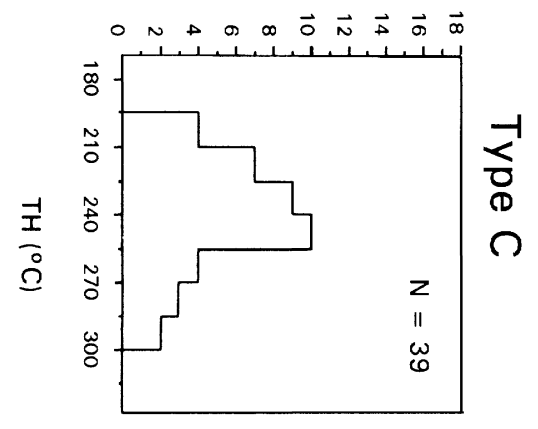

Frequency

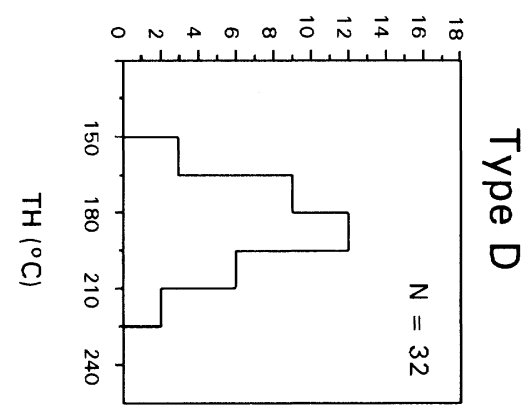

\section{MARI ROSA}

Frequency
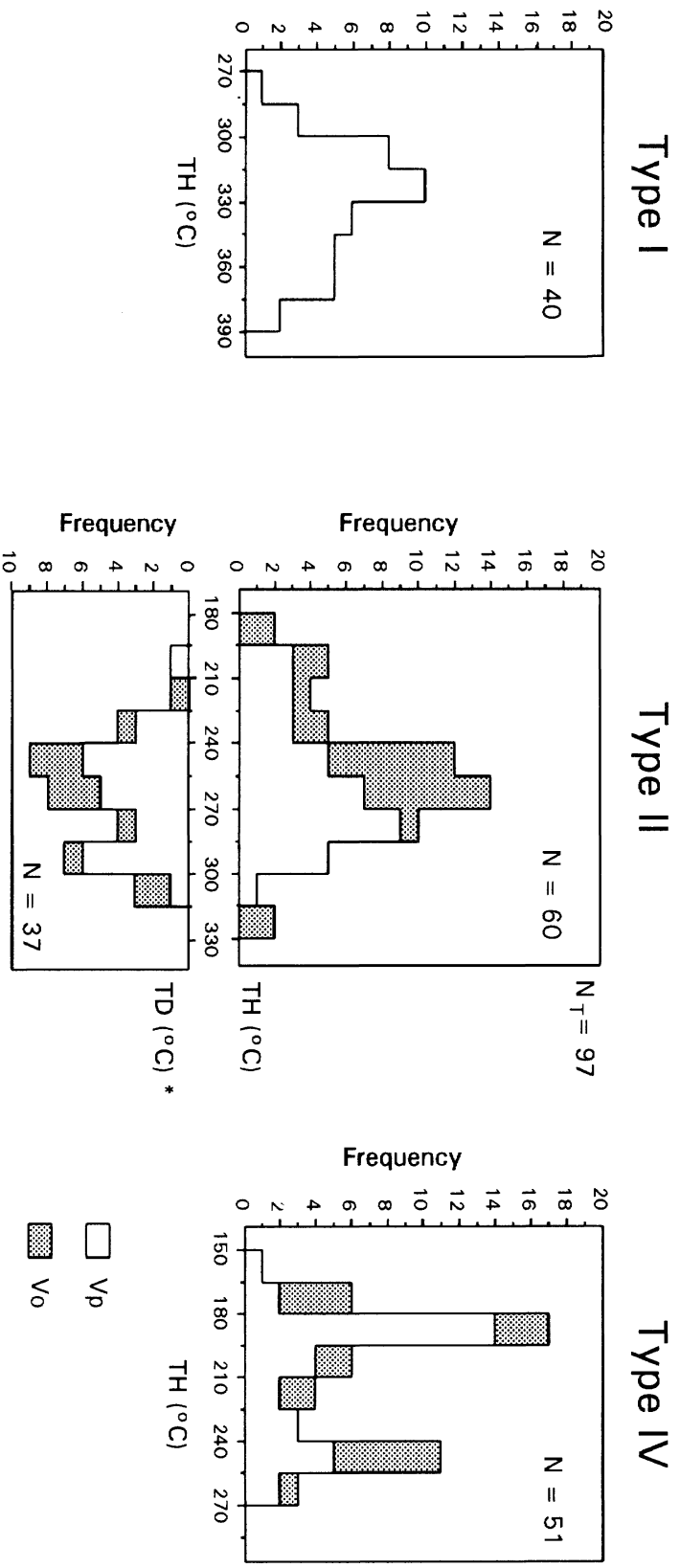

Fig. 5. Histograms of total homogenization temperatures (TH) for the different fluid inclusion types at Mari Rosa and El Juncalón. For type II (Mari Rosa), a histogram of decrepitation temperature (TD) is also given. Vp and Vo: vein types at Mari Rosa. 
with minor $\mathrm{CH}_{4}$ (Table 1). However, no phase transitions were observed in this fraction on cooling to $-170^{\circ} \mathrm{C}$. On warming, ice melting took place between $-5.2^{\circ}$ and $-1.5^{\circ} \mathrm{C}$ and there is no evidence of clathrates. Total homogenization temperatures are scattered between $160^{\circ}$ and $266^{\circ} \mathrm{C}(\mathrm{L})$, with two peaks in the $\mathrm{TH}$ histogram: a main one corresponding to $190^{\circ} \mathrm{C}$ and a secondary one located at $250^{\circ} \mathrm{C}$ (Fig. 5).

In these inclusions, the absence of relevant Th $\left(\mathrm{N}_{2}-\mathrm{CH}_{4}\right)$ prevents the calculation of molar volumes for their non-aqueous constituents, and hence, also the bulk molar volumes and compositions. Salinity, estimated from Tm ice in the absence of clathrate, ranges between 2.5 and $9 \%$ eq. $\mathrm{NaCl}$.

\section{El Juncalón}

\section{Inclusion types}

Based on optical (number of phases and degree of filling) and compositional features, five types of inclusions are recognized ${ }^{2}$. Most of them are water-bearing inclusions (types $\mathrm{A}, \mathrm{B}, \mathrm{C}$ and $\mathrm{D}$ ), but monophase vapour inclusions (type E) are also observed. However, the latter may contain up to $10 \%$ vol. $\mathrm{H}_{2} \mathrm{O}$ without being detected by optical means. The fluid-inclusion types are (Table 3):

- Type A: $(\mathrm{L}+\mathrm{V})$. Inclusions with very variable vapour/liquid ratios $(\mathrm{Vv} / \mathrm{Vt}=0.8-0.2)$. Three subgroups are distinguished: $\mathrm{A}_{1}(0.8-0.5), \mathrm{A}_{2}$ (0.5-0.3) and $\mathrm{A}_{3}(0.3-0.2) . \mathrm{CH}_{4}$ is the only volatile component detected by Raman in most of the inclusions.

- Type B: $(\mathrm{S}+\mathrm{L}+\mathrm{V})$. Vv/Vt $=0.3-0.5$. No volatiles were detected by Raman. The solid phase does not disolve on heating, thus suggesting that it is a trapped solid rather than a daughter mineral. Raman analysis of this phase showed similar but less intense Raman spectrum as the host mineral (quartz).

- Type C: $(\mathrm{L}+\mathrm{V})$. Vv/Vt $=0.1-0.2$. Vapour phase is composed of $\mathrm{N}_{2}(\mathrm{X}>0.5)$ and $\mathrm{CH}_{4}$.

- Type D: $(\mathrm{L}+\mathrm{V})$. Vv/Vt. < 0.1 No Raman data available.

- Type E: Vv/Vt > 0.9. $\mathrm{CH}_{4}$-bearing inclusions, with up to 0.1 vol. $\mathrm{H}_{2} \mathrm{O}$.

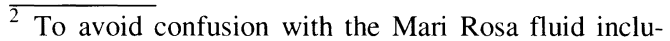
sion types, letters (A to E) are used to denote the El Juncalón types.
}

Type A, B and E inclusions occur in the brecciated cores of polygonal quartz crystals. These are dark areas characterized by closelyspaced trails of leaked and open inclusions, in which regularly shaped inclusions (type A, B and E) are scattered. The coexisting type A, B and $E$ inclusions show common features such as similar composition $\left(\mathrm{H}_{2} \mathrm{O} \pm \mathrm{CH}_{4}\right)$ and microthermometric data (salinity and $\mathrm{TH}$ ), but also some striking differences, mostly regarding the degree of filling. These highly variable vapour/liquid ratios can be explained as the result of leakage in some of the inclusions, with partial or total loss of water as a consequence of post-trapping brecciation. As stated above, a brittle deformation took place between stages 1 and 2 along the fault zones (Fig. 3). Therefore, all these inclusions belong to the same fluid circulation episode and correspond to relic inclusions trapped during stage 1 .

Both type $\mathrm{C}$ and $\mathrm{D}$ occur within the rims of the polygonal quartz crystals or cross-cutting the cores. Type $\mathrm{C}$ appears as isolated inclusions (Fig. 4 d), in groups or within arrays. They postdate types A, B and E and are not affected by the brecciation episode. Finally, type D inclusions are secondary and are confined to sealed cracks, postdating all the other types.

\section{Fluid inclusion data}

Type A inclusions are very abundant and correspond to biphase $\mathrm{H}_{2} \mathrm{O}-\mathrm{NaCl}-\mathrm{CH}_{4}$ inclusions. The Raman signal is rather weak, suggesting a low fluid density. This is supported by the absence of phase transitions within the vapour phase on cooling to $-170^{\circ} \mathrm{C}$. $\mathrm{Tm}$ ice between $-2.9^{\circ} \mathrm{C}$ and $-0.2^{\circ} \mathrm{C}$ indicates a salinity lower than $5 \%$ eq. $\mathrm{NaCl}$. The presence of clathrate can rarely be recognized above $0^{\circ} \mathrm{C}$. $\mathrm{TH}$ in these inclusions ranges between $285^{\circ}$ and $390^{\circ} \mathrm{C}$, generally into the liquid, although critical homogenization is often observed in $A_{1}$ and $A_{2}$ inclusions. Higher $\mathrm{TH}$ values are observed with increasing volumetric ratios $(\mathrm{Vv} / \mathrm{Vt})$, with two populations distinguished in the $\mathrm{TH}$ histogram (Fig. 5): a maximum at $345^{\circ} \mathrm{C}$ corresponding to type $A_{1}$ and $\mathrm{A}_{2}$ (along with type $\mathrm{B}$, described below; all together $\mathrm{Vv} / \mathrm{Vt}>0.3$ ) and another at $320^{\circ} \mathrm{C}$ represents type $\mathrm{A}_{3}(\mathrm{Vv} / \mathrm{Vt}<0.3)$. As stated previously, some of these inclusions show evidence of post-trapping leakage. Only type $\mathrm{A}_{3}$, characterized by lower volumetric ratios and a welldefined individual $\mathrm{TH}$ peak, are considered to 
represent the original fluid circulating when type A inclusions were trapped.

In these inclusions, the absence of phase transitions in the vapour phase at low temperatures indicate a density of $\mathrm{CH}_{4}$ below $0.02 \mathrm{gr.cm}^{-3}$ (data from Deaton \& Frost, 1946; Angus et al., 1976; in Durisova et al., 1992). Bulk composition and density were calculated from a selected $\mathrm{A}_{3}$ inclusion based on the method by Ramboz et al. (1985) and Ramboz \& Charef (1988). The density for the aqueous phase containing $2.6 \mathrm{wt} \%$ $\mathrm{NaCl}$ is $1.01 \mathrm{gr.cm}^{-3}$ at $25^{\circ} \mathrm{C}$ (Potter \& Brown, 1977). Total content of $\mathrm{CH}_{4}$ in the fluid is up to 0.044 mole fraction, along with 0.006 mole fraction $\mathrm{NaCl}$ and 0.95 mole fraction $\mathrm{H}_{2} \mathrm{O}$. The bulk

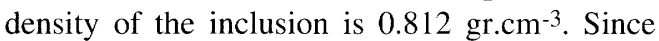
the amount of volatiles can be considered as negligible, the homogenization pressure can be obtained from the $\mathrm{H}_{2} \mathrm{O}-\mathrm{NaCl}$ system: $\mathrm{PH}=106$ bars for $\mathrm{TH}=318^{\circ} \mathrm{C}$.

Type B shows Tm ice between -2.5 and $-1.0^{\circ} \mathrm{C}$, indicating salinities between 2 and $4 \%$ eq. $\mathrm{NaCl}$, while $\mathrm{TH}$ are between $345^{\circ}$ and $385^{\circ} \mathrm{C}$ ( $\mathrm{L}$ or C). No volatiles were detected in the vapour phase by Raman analysis. By their characteristics, type $B$ inclusions are equivalent to type $A_{1}$ but they also contain trapped solids phases. For this reason, type $\mathrm{B}$ homogenization temperatures are plotted in the same histogram as type A inclusions (Fig. 5).

Type C (Fig. 4 d) are $\mathrm{H}_{2} \mathrm{O}-\mathrm{NaCl}-\mathrm{N}_{2}-\mathrm{CH}_{4}$ inclusions and their microthermometric behaviour at low temperature is very similar to that of type II inclusions at Mari Rosa. On cooling, approximately when the water freezes in the liquid part, a round solid phase (probably clathrate) nucleates within the bubble. No further changes are observed in the volatile fraction as the temperature is lowered to $-170^{\circ} \mathrm{C}$, indicating a very low density. On warming, the clathrate is not observed above $-25^{\circ} \mathrm{C}$ to $-10^{\circ} \mathrm{C}$ although final melting, estimated during a cyclic cooling (Collins, 1979), occurs around $+5^{\circ} \mathrm{C}$. Tm ice between $-2.8^{\circ} \mathrm{C}$ and $-0.8^{\circ} \mathrm{C}$ indicates salinities between 1.5 and $5 \%$ eq. $\mathrm{NaCl}$. The influence of clathrate on $\mathrm{Tm}$ ice can be considered as negligible given that bulk concentration of volatiles (i.e. $\mathrm{CH}_{4}$ and $\mathrm{N}_{2}$ ) is low (Collins, 1979; Hanor, 1980). Furthermore, salinities in the range of the other water-bearing inclusions support this asumption. Total homogenization occurs between 200 and $300^{\circ} \mathrm{C}$ (L) with a maximum of $250^{\circ} \mathrm{C}$ (Fig. 5).

Type $\mathrm{D}$ are small aqueous inclusions, with $\mathrm{Vv} / \mathrm{Vt}<0.1$. Raman data of the vapour phase could not be obtained. Tm ice is between $-2.1^{\circ}$ and $-0.5^{\circ} \mathrm{C}$, with salinities ranging from 0.8 to $4 \%$ eq. $\mathrm{NaCl}$. TH is between $160^{\circ}$ and $225^{\circ} \mathrm{C}$ into the liquid (Fig. 5). This type of inclusion is similar to the type IV of Mari Rosa.

Finally, type E inclusions are monophase at room temperature and are composed of $\mathrm{CH}_{4}$, although they may contain up to $10 \%$ vol. $\mathrm{H}_{2} \mathrm{O}$. No phase transitions were observed on cooling to $-170^{\circ} \mathrm{C}$. However, the development of a water rim was observed in one type $\mathrm{E}$ inclusion during a heating cycle, increasing in volume with temperature. Total homogenization for that inclusion was $\mathrm{TH}>400^{\circ} \mathrm{C}$ into L. This behaviour suggest that type $\mathrm{E}$ inclusions could be similar to type $\mathrm{A}$ inclusions, with a $\mathrm{Vv} / \mathrm{Vt}>90 \%$.

\section{Discussion and conclusions}

\section{Mineral deposition and fluid evolution}

\section{Mari Rosa}

The early stage of mineral deposition is characterized by aqueous-carbonaceous fluids (type I inclusions) circulating at a minimum temperature of $300 \pm 50^{\circ} \mathrm{C}$ (Table 4). This hydrothermal stage is only recorded in $\mathrm{Vp}$ veins in which minor arsenopyrite and traces of pyrite precipitated along with quartz $\left(\mathrm{Q}_{1}\right)$, obliterating most of the older metamorphic quartz texture.

The second stage is the most noteworthy event, leading to the deposition of a massive stibnite ore containing up to $30 \mathrm{ppm} \mathrm{Au} \mathrm{(Ortega,} \mathrm{1993)}$ within Vo veins. Evidence of boiling during this stage is provided by the coexistence of liquidrich (type II) and vapour-rich (type III) inclusions. In this process, the more volatile components were preferentially partitioned towards the vapour fraction resulting in a higher concentration of $\mathrm{CH}_{4}$ and $\mathrm{N}_{2}$ in type III V-rich inclusions (Fig. 6). Since homogenization PT values equal trapping PT if boiling is achieved (Ramboz et al., 1982), microthermometric data for type II inclusions indicate that $0.9-1 \mathrm{kbar}$ and $275-300^{\circ} \mathrm{C}$ are the most probable PT conditions for this stage. Besides, isochores calculated ${ }^{3}$ from repre-

\footnotetext{
3 Isochores were calculated using MRK equation of Holloway, with the FLINCOR computer program (Brown, 1989).
} 


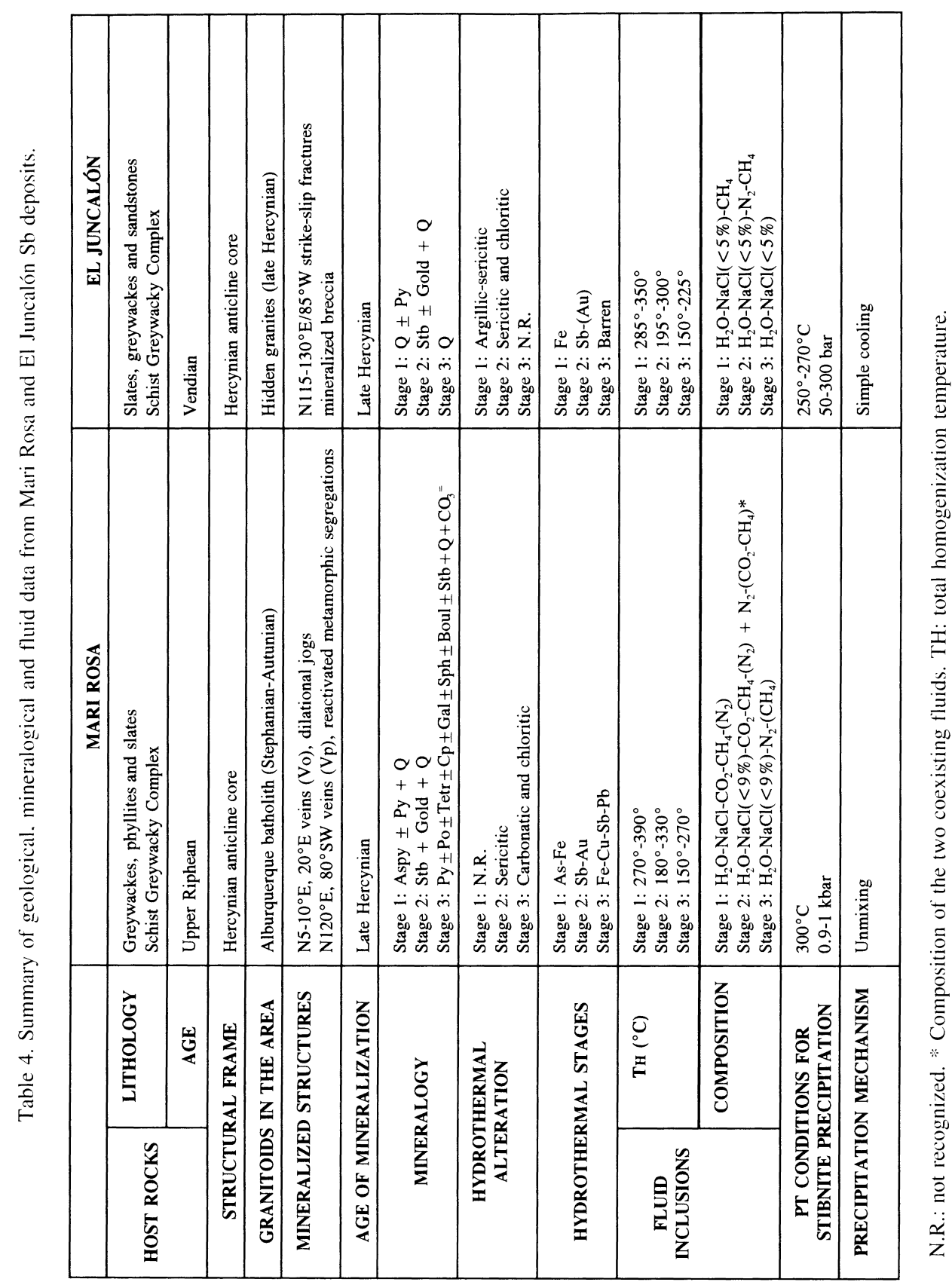

sentative type III inclusions (with $7 \%$ vol. $\mathrm{H}_{2} \mathrm{O}$ ) indicate pressures of $0.9-0.95 \mathrm{kbar}$ at $\mathrm{T}=300^{\circ} \mathrm{C}$, which are consistent with the values obtained from type II inclusions. Experimental data for the $\mathrm{H}_{2} \mathrm{O}-\mathrm{CO}_{2}-\mathrm{CH}_{4}-\mathrm{N}_{2}$ system are not available. However, an estimation of the theoretical com- position of coexisting fluids has been made from PTX projection of the two-phase region in the $\mathrm{H}_{2} \mathrm{O}-\mathrm{CH}_{4}$ (Welch, 1973) and $\mathrm{H}_{2} \mathrm{O}-\mathrm{N}_{2}$ (Japas \& Franck, 1985) binary systems. According to this estimation, for the given PT conditions, the mole fraction of volatiles is $0.75-0.8$ (V-rich fluid) and 


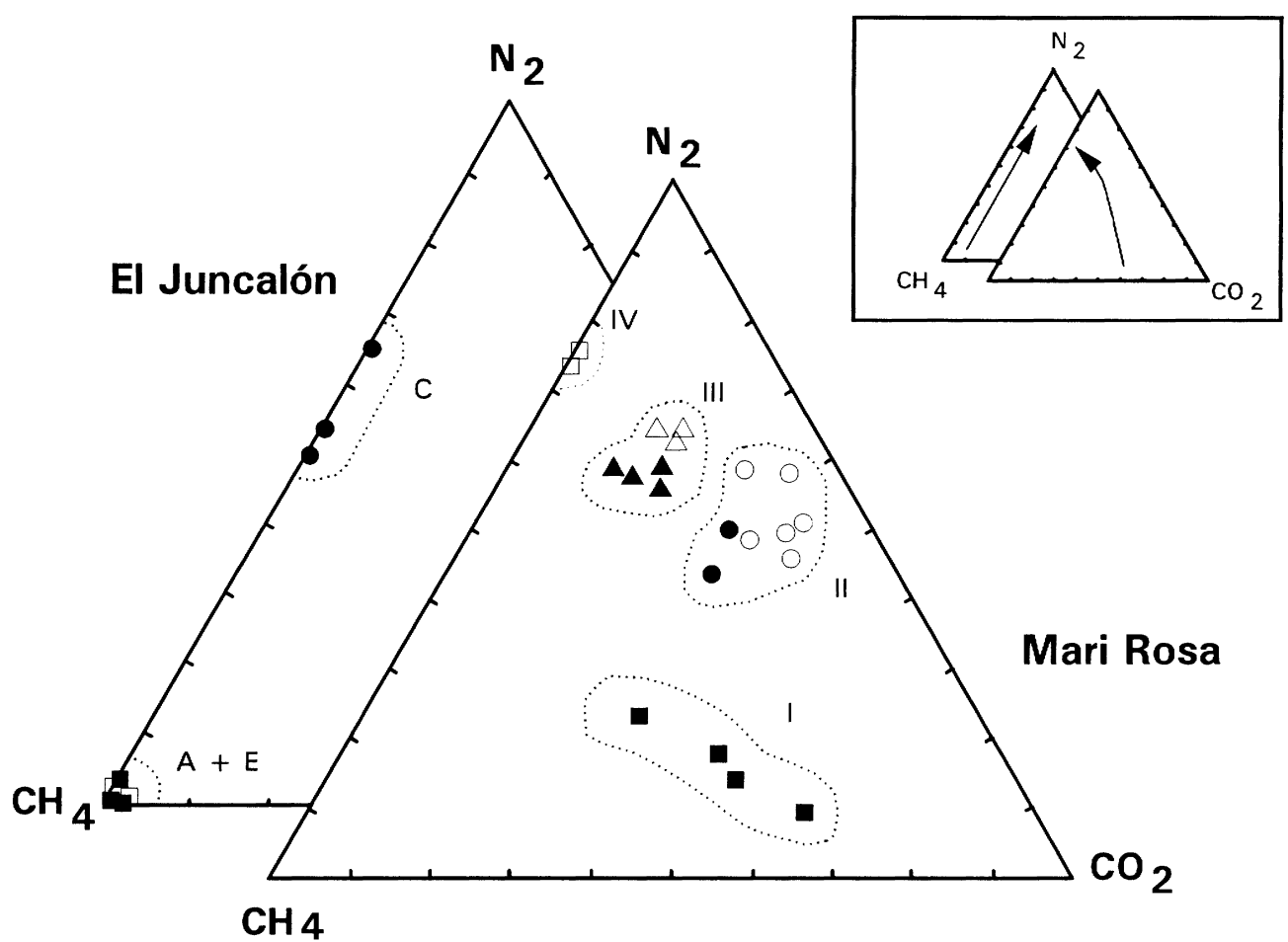

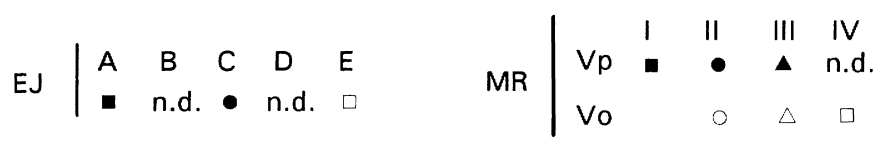

Fig. 6. Composition (molar fraction) and evolution trends for volatiles in the ternary system $\mathrm{CO}_{2}-\mathrm{CH}_{4}-\mathrm{N}_{2}$ for Mari Rosa and El Juncalón fluids.

0.05 (L-rich fluid) (Ortega et al., 1991b). These values are consistent with the bulk composition of type III (containing $\mathrm{H}_{2} \mathrm{O}<10 \%$ vol., Table 2) and type II inclusions, respectively, thus reaffirming that they are the end-members of an immiscibility process. Since barren quartz containing type II and III inclusions is found in Vp veins, it is assumed that the fluid was already unmixed when circulating through these veins. Therefore, mineral deposition must have been strongly controlled by the mechanical behaviour of Vo veins, allowing the formation of dilational jogs during fault movement. This resulted in fluid influx into the open cavities and subsequent pressure drops (e.g. Sibson, 1987, 1990) which triggered fluid unmixing and massive precipitation of stibnite. This process must have been sus- tained for as long as the cavities remained opened to the circulation of fluids.

The third hydrothermal stage is characterized by mainly aqueous fluids (type IV inclusions) associated to the deposition of a wide variety of sulphides and sulphosalts of $\mathrm{Pb}, \mathrm{Cu}, \mathrm{Fe}, \mathrm{Ni}$ and Co (Table 4). The upper temperature limit for this late stage is defined by the previous boiling episode at $300^{\circ} \mathrm{C}$, and was probably no higher than $270^{\circ} \mathrm{C}$ (maximum TH; Fig. 5). No major changes in salinity are recorded from stage 2 (liquid-rich fluid) to stage 3 .

The overall fluid evolution in the deposit shows a decreasing trend in the temperatures of circulation and a progressive enrichment in the bulk water content. Besides, volatile composition shows $\mathrm{N}_{2}$ enrichment towards the late stages of 


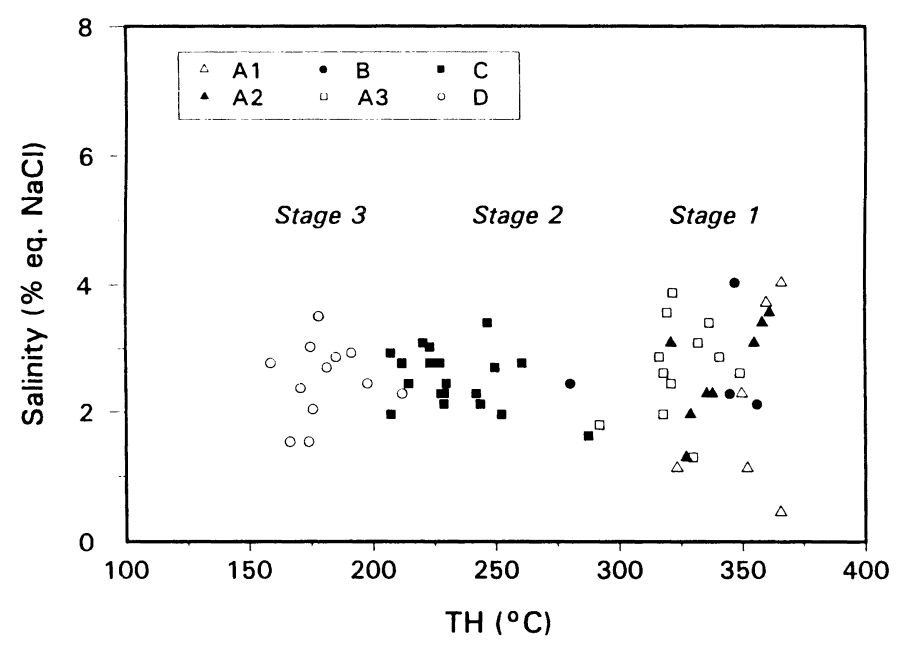

Fig. 7. Homogenization temperatures $(\mathrm{TH})$ versus salinities in fluid inclusions from El Juncalón.

fluid evolution. The fluid which unmixed and gave rise to populations II and III in Mari Rosa had a volatile composition located between the two corresponding domains in the gas triangle (Fig. 6). Hence, an increase in the relative proportions of $\mathrm{N}_{2}$ occurred during cooling after population I was trapped. This evolution trend continued until the third hydrothermal stage.

\section{El Juncalón}

Intense argillic-sericitic alteration developed at El Juncalón during the first hydrothermal stage, along with the precipitation of minor pyrite (Fig. 3, Table 4). During this stage, a $\mathrm{H}_{2} \mathrm{O}-\mathrm{NaCl}-\mathrm{CH}_{4}$ fluid circulated at a minimum temperature of $320^{\circ} \mathrm{C}$ (TH mode for type A3 inclusions) and a minimum pressure of 100 bars. The second hydrothermal stage postdates a brecciation episode resulting from strike-slip movement along the main fault. During this stage, stibnite filled cracks and cavities within the recrystallized quartz and cemented the breccia. Fluid inclusions associated with stibnite deposition (type C) contain a $\mathrm{N}_{2}-\mathrm{CH}_{4}$-bearing aqueous fluid (Table 3; Fig. 6). In contrast to the case at Mari Rosa, no evidence indicates the existence of boiling during this stage. Minimum circulation temperatures are around $250^{\circ} \mathrm{C}$ (modal TH, Fig. 5). Since this fluid contained very-low-density gases, their influence on PT evolution can be considered as negligible. Therefore, minimum $\mathrm{P}$ can be estimated in the
$\mathrm{H}_{2} \mathrm{O}-\mathrm{NaCl}$ system (Brown \& Lamb, 1989), yielding values as low as 50 bar. If antimony solubility data (Spycher \& Reed, 1989; Krupp, 1988) are taken into account, saturation in antimony seems improbable above $270^{\circ} \mathrm{C}$ (Munoz et al., 1992). For a fluid inclusion with 2.7 wt. $\% \mathrm{NaCl}$ and $\mathrm{TH}=250^{\circ} \mathrm{C}$ (Fig. 7), the corresponding isochore 4 yields a pressure value of 300 bar for a temperature of $270^{\circ} \mathrm{C}$. This constrains the probable PT conditions for stibnite precipitation at El Juncalón within the range $250-270^{\circ} \mathrm{C}$ and $50-300$ bar. As shown in Fig. 7, the mineralizing fluid at El Juncalón underwent simple cooling with no major changes in salinity (at around 1-5 wt \% $\mathrm{NaCl}$ ), a trend that is maintained until the end of the hydrothermal history. According to experimental data (Wood et al., 1987; Krupp, 1988) a decrease of fluid temperature $\left(\mathrm{e} . \mathrm{g}\right.$. from $350^{\circ} \mathrm{C}$ to $200^{\circ} \mathrm{C}$ ) would dramatically reduce antimony solubility by a factor of up to ten, leading to precipitation of stibnite even from initially undersaturated solutions. Therefore, simple cooling seems to be an adequate mechanism for stibnite precipitation at El Juncalón. Finally, the third hydrothermal stage is characterized by mainly aqueous fluids trapped at minimum temperatures of $190^{\circ} \mathrm{C}$ (modal $\mathrm{TH}$ ) with salinity values within

\footnotetext{
$\overline{4}$ Isochore calculated with FLINCOR program (Brown, 1989) in the $\mathrm{H}_{2} \mathrm{O}-\mathrm{NaCl}$ with the equation of Brown \& Lamb (1989).
} 
the same range as the previous stages. No metal deposition is associated with this stage.

\section{Mari Rosa and El Juncalón: contrasting cases}

Fluids associated with ore deposition in Mari Rosa and El Juncalón (Table 4) belong to the $\mathrm{H}_{2} \mathrm{O}-\mathrm{NaCl}-\mathrm{CO}_{2}-\mathrm{CH}_{4}-\mathrm{N}_{2}$ system, with the exception of $\mathrm{CO}_{2}$ which is absent at El Juncalón. They evolved by progressive cooling from initial circulation temperatures close to $400^{\circ} \mathrm{C}$ in the early stages to around $150^{\circ} \mathrm{C}$ in the late episodes. In both deposits, the volatile fraction of the fluids recorded an enrichment in $\mathrm{N}_{2}$ during the hydrothermal evolution. Besides, there was an increase in the bulk water content. Salinity stayed at moderate values $(<9 \mathrm{wt}$. $\% \mathrm{NaCl})$ during the whole process. However, major differences arise from the contrasting ore depositional mechanisms. At Mari Rosa, massive stibnite deposition resulted from immiscibility developed at $300^{\circ} \mathrm{C}$ and 0.9-1 kbar. Unmixing of the fluid was induced by sudden pressure drops in dilational jogs during the low-angle faults movements. Simple cooling of the fluid, with no salinity changes, was the driving mechanism for stibnite deposition around $250^{\circ}-270^{\circ} \mathrm{C}$ and $50-300$ bars at $\mathrm{El}$ Juncalón.

Differences in the temperature of stibnite precipitation between Mari Rosa and El Juncalón can be explained in terms of the mechanism of precipitation involved in each deposit. Ore solutions are likely to be saturated in antimony only below $270^{\circ} \mathrm{C}$ (Munoz et al., 1992). According to experimental data (Wood et al., 1987; Krupp, 1988) a decrease in the fluid temperature would dramatically reduce antimony solubility, leading to precipitation of stibnite. However, phase separation during boiling at Mari Rosa would have led to a strong partitioning of antimony towards the liquid phase (e.g. Spycher \& Reed, 1989), which would have resulted in saturation and sudden precipitation of stibnite at $300^{\circ} \mathrm{C}$, a temperature higher than the value predicted from solubility calculations. The contrasted precipitation mechanisms also account for most of the textural features of the deposits, with massive mineralization at Mari Rosa and low stibnite/quartz ratios at El Juncalón. Boiling at $\mathrm{T} \leq 300^{\circ} \mathrm{C}$ would result in the precipitation of similar amounts of quartz and metals, while simple cooling would induce deposition of about ten times more silica with the same amount of metals (Drummond \& Ohmoto, 1985).
Finally, pressure data for both deposits indicate that El Juncalón corresponds to a relatively shallow-seated deposit, while Mari Rosa formed at a deeper level. In this sense, attention should be paid to the fact that late Hercynian granites do not crop out in the area of El Juncalón. It should be noted that this deposit is located within the boundary between the so-called "Suboutcroping Granite Zone" and the "Deep Seated Granite Zone" (ITGE, 1993). Since these concealed granitoids are equivalent to those of the Alburquerque Batholith, erosion rates should have been very different, thus allowing preservation of a relatively shallow-seated deposit such as El Juncalón.

\section{Late Hercynian Sb mineralizations in France, Portugal and Spain: a comparison}

By the end of the Hercynian orogeny both the Hesperian Massif and the French Massif Central had become overthickened and overheated unstable masses which eventually collapsed through major low-angle extensional detachment systems in late Hercynian times (Seranne \& Malavieille, 1993; Doblas et al., 1994). Extension in the French Massif Central is directly related to the formation of $\mathrm{Sb}$ veins during Westphalian/Stephanian times. Low-angle detachments pumped up hydrothermal fluids to nearsurface level (ca. $1000 \mathrm{~m})$ where stibnite deposition could take place (Munoz et al., 1992). In contrast to the French Massif Central, the extensional collapse of the Spanish Hercynian Massif (Carboniferous/Permian) mainly affected its central part (Spanish Central System; Doblas et al., 1994). The western sector (western Spain, Portugal) does not show clear-cut structural indicators of similar phenomena during the same time-span. This is to be regarded as a distal tectonic zone which most probably underwent synextensional deep delamination enhancing heat flow, lower crustal melting and magma generation (e.g. Inger, 1993; Platt \& England, 1994). Coeval local compressions (e.g. low-angle reverse faults at Mari Rosa) may have occurred in response to upper crustal accomodation in the west in response to the extensional collapse taking place in the central part of the Hesperian Massif. Under these conditions, late Hercynian plutonic activitiy would have resulted in an elevation of the geothermal gradient which would have triggered widespread hydrothermal activity as observed in the western part of the Iberian Peninsula. These processes gave rise to a 


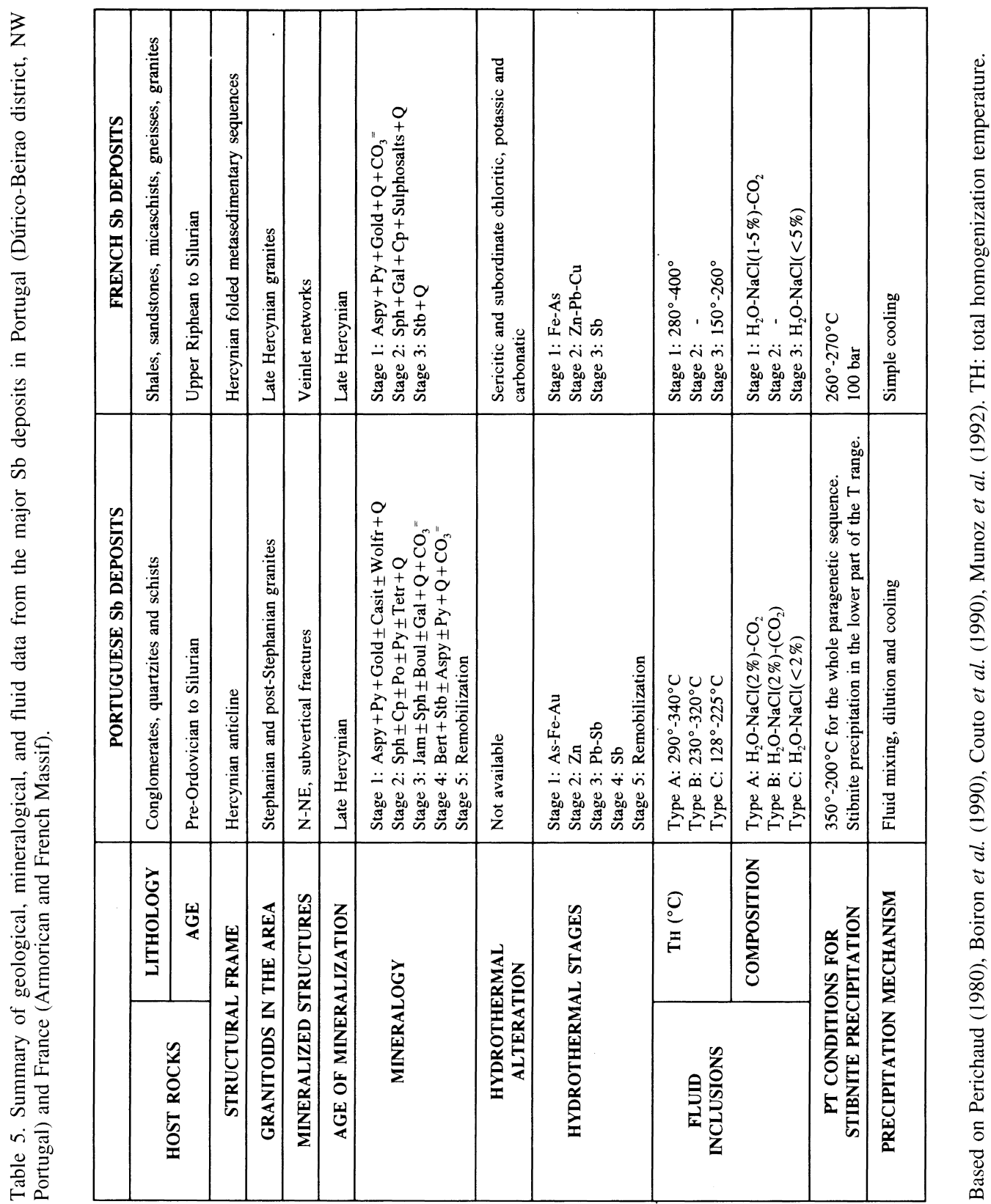

wide variety of mineral deposits: $\mathrm{Sn}-\mathrm{W}, \mathrm{Sb}-\mathrm{Au}$, $\mathrm{Pb}-\mathrm{Zn}$, among others (Gumiel \& Arribas, 1987; Couto et al., 1990; Ortega, 1993).

The mineralogy of the late Hercynian $\mathrm{Sb}-\mathrm{Au}$ deposits of the Iberian Peninsula and France is characterized by stibnite as the main ore mineral, with the almost ubiquitous presence of minor ar- senopyrite, pyrite and $\mathrm{Pb}, \mathrm{Zn}$ and $\mathrm{Cu}$ sulphides and/or sulphosalts (Tables 4 and 5). Gold is associated either with early arsenopyrite (France, Portugal) or with stibnite (Spain). Ore-forming fluids are aqueous-carbonaceous solutions during the early stages, evolving to mostly aqueous fluids through the course of hydrothermal activ- 
ity. However, the presence of $\mathrm{N}_{2}$ and $\mathrm{CH}_{4}$ as significant components in the fluids of the Spanish deposits contrasts with the Portuguese and French examples in which $\mathrm{CO}_{2}$ is the main volatile. Temperatures for fluid circulation are within the same range in all cases, with stibnite precipitation between $260^{\circ}$ and $300^{\circ} \mathrm{C}$. Pressure conditions vary from 1 kbar (Mari Rosa, Spain) to a maximun of few hundred bars (El Juncalón, Spain, and the French deposits), thus indicating different depths for antimony deposition. Finally, progressive cooling of the fluids resulted in stibnite precipitation in most of the deposits, exceptat Mari Rosa where fluid immiscibility was the triggering factor for mineral deposition. As a whole, post-orogenic antimony metallogeny in the Iberian Peninsula and France shows a fairly similar pattern, with some special features at Mari Rosa. The main differences result from the local geological setting which developed within an overall extensional regime during the late Hercynian times.

Acknowledgements: This research was funded by the Spanish Ministry of Education through a post-graduate scholarship. It greatly benefitted from discussions with J.L.R. Touret, R. Oyarzun, J. Dubessy and A. Barker. Critical review of the manuscript by an anonymous referee and U.F. Hein resulted in improvement and clarification of the text. We extend our thanks to E.A.J. Burke for help and assistance with the Raman analyses at the Free University of Amsterdam. The Raman facilities (Amsterdam) were subsidized by the Netherlands Organization for Scientific Research (N.W.O.). J. McGowan is thanked for revision of the English text.

\section{References}

Angus, S., Amstrong, B., Renck, K.M. (1976): International Thermodynamic Tables of Fluid State, vol. 5: Methane. Pergamon Press, Oxford, 385 pp.

Bascones, L. \& Martín Herrero, D. (1982): Mapa Geológico de España, E/1:50.000. Hoja 674-675, Sever-Santiago de Alcántara. I.G.M.E.

Bodnar, R., Binns, P.R., Hall, D.L. (1989): Synthetic fluid inclusions - VI. Quantitative evaluation of the decrepitation behaviour of fluid inclusions in quartz at one atmosphere confining pressure. $J$. metamorphic Geol., 7, 229-242.

Boiron, M.C., Cathelineau, M., Dubessy, J., Bastoul, A.M. (1990): Fluids in Hercynian Au veins from the French Variscan belt. Mineral. Mag., 54, 231-243.

Brown, P.E. (1989): FLINCOR: A microcomputer program for the reduction and investigation of fluid inclusion data. Am. Mineral., 74, 1390-1393.
Brown, P.E. \& Lamb, W.M. (1989): P-V-T properties of fluids in the system $\mathrm{H}_{2} \mathrm{O}-\mathrm{CO}_{2}-\mathrm{NaCl}$ : New graphical presentations and implications for fluid inclusion studies. Geochim. Cosmochim. Acta, 53, 1209-1221.

Collins, P.L.F. (1979): Gas hydrate in $\mathrm{CO}_{2}$ bearing fluid inclusions and the use of freezing data for estimation of salinity. Econ. Geol., 74, 1435-1444.

Couto, H., Roger, G., Moëlo, Y., Bril, H. (1990): Le district à antimoine-or Durico-Beirao (Portugal): évolution paragénétique et géochimique; implications métallogéniques. Mineral. Dep., 25, 69-81.

Deaton, W.H. \& Frost, E.M. (1946): Gas hydrates and their relation to the operation of natural gas pipelines. U.S. Bur. Mines, Monogr., 8, 103 p.

Díez Balda, M.A., Vegas, R., González Lodeiro, F. (1990): Autochthonous Sequences: Structure. in: "Premesozoic Geology of Iberia". R.D. Dallmeyer and E. Martínez, Eds, Springer Verlag, Berlin, 172188.

Doblas, M., Oyarzun, R., Sopeña, A., Lopez Ruiz, J., Capote, R., Hernández Enrile, J.L., Hoyos, M., Lunar, R., Sanchez Moya, Y. (1994): Variscan late Variscan - early Apine progressive extensional collapse of central Spain. Geodinam. Acta, 7, 1-14.

Drummond, S.E. \& Ohmoto, H. (1985): Chemical evolution and mineral deposition in boiling hydrothermal systems. Econ. Geol., 80, 126-147.

Durisova, J., Sztacho P., Dubessy J. (1992): A fluid inclusion study of $\mathrm{Au}-\mathrm{W}$ stratiform mineralization at Orlík near Humpolec, Czechoslovakia. Eur. J. Mineral., 4, 965-976.

Gallego, M. \& Gumiel, P. (1993): Li-mineralization at Tres Arroyos (Alburquerque, Badajoz) as a result of the mineralogical and geochemical evolution of the Alburquerque batholith. Geogaceta, 13, 29-32.

Gumiel, P. (1983): Metalogenia de los yacimientos de antimonio de la Península Ibérica. Tecniterrae, 54, 6-120.

Gumiel, P. \& Arribas, A. (1987): Antimony deposits in the Iberian Peninsula. Econ. Geol., 82, 1453-1463.

Gumiel, P., Arribas, A., Saavedra, J. (1976): Geología y metalogenia del yacimiento de estibina-scheelita de San Antonio, Alburquerque, Badajoz. Studia Geol., 10, 61-93.

Hanor, J.S. (1980): Dissolved methane in sedimentary brines: potential effect on the PV̄T properties of fluid inclusions. Econ. Geol., 75, 603-609.

Inger, S. (1993): Magmatic signatures of late-orogenic extension. in: "Late orogenic extension in Mountain belts" Seranne M. \& Malavieille J., eds. Doc. BRGM Fr., 219, 96-97.

ITGE (1993): Exploración e Investigación de fosfatos sedimentarios en las Reservas Hespérica 1-7 y Malagón y de sustancias metálicas en las Reservas de Valdelacasa, Alcudia y Guadalupe. Segunda Fase: 1987-1990. Tomo I: Introducción al proyecto y Contexto geológico regional. Tomo IV: Ex- 
ploración geológico minera de sustancias metálicas. Fondos Documentales del Instituto Tecnológico Geominero de España.

Japas, M.L. \& Franck, E.U. (1985): High pressure phase equilibria and $\mathrm{P}-\overline{\mathrm{V}}-\mathrm{T}$ data of water-nitrogen system to $673^{\circ} \mathrm{K}$ and $250 \mathrm{MPa}$. Ber. Bunsenges Phys. Chem., 89, 793-800.

Kerkhof, A.M., van den (1988): The system $\mathrm{CO}_{2}-\mathrm{CH}_{4}-$ $\mathrm{N}_{2}$ in fluid inclusions: Theoretical modeling and geological applications. Ph.D. Thesis, Free University, Amsterdam, 206 pp.

Krupp, R.E. (1988): Solubility of stibnite in hydrogen sulfide solutions, speciation, and equilibrium constants, from 25 to $350^{\circ} \mathrm{C}$. Geochim. Cosmochim. Acta, 52, 3005-3015.

Leroy, J. (1979): Contribution à l'étalonnage de la pression interne des inclusions fluides lors de leur décrépitation. Bull. Minéral., 102, 584-593.

Munoz, M., Courjault-Rade P., Tollon F. (1992): The massive stibnite veins of the French Paleozoic basement: a metallogenic marker of Late Variscan brittle extension. Terra Nova, 4, 171-177.

Ortega, L. (1993): Caracterización de los procesos hidrotermales en las mineralizaciones de antimonio de Mari Rosa y El Juncalón (Zona Centro Ibérica meridional). Ph.D. Thesis, Univ. Complutense de Madrid, 386 pp.

Ortega, L., Vindel, E., Dubessy J. (1991a): Fluid evolution in a boiling system around a cooling granite: a Hercynian antimony deposit case study. Plinius, 5, 162-163.

Ortega, L., Vindel, E., Beny, C. (1991b): C-O-H-N fluid inclusions associated with gold-stibnite mineralization in low-grade metamorphic rocks, Mari Rosa mine, Caceres, Spain. Mineral. Mag., 55, 235-247.

Perichaud, J.J. (1980): L'antimoine, ses minerais et ses gisements. Synthèse gîtologique sur les gisements du Massif Central français. Chron. Rech. Min., 456, 64 pp.

Platt, J.P. \& England, P.C. (1994): Convective removal of lithosphere beneath mountain belts: thermal and mechanical consequences. Amer. Jour. Sci., 294, 307-336.

Portugal, M., Santos Oliveira, J.M., Santarem, R. (1971): Ocorrencias de antimonio no Norte de Portugal. Congr. Hispano-Luso-Americano Geol. Econ. 1, Madrid-Lisboa, Vol. 1, 597-617.

Potter, R.W. \& Brown, D.L. (1977): The volumetric properties of aqueous sodium chloride solutions from $0{ }^{\circ} \mathrm{C}$ to $500^{\circ} \mathrm{C}$ at pressures up to 2000 bars based on a regression of available literature data. U.S. Geol. Survey, Open file Rep. 75-636, 31 pp.

Poty, B., Leroy, J., Jachimowicz, L. (1976): A new device for measuring temperatures under the microscope: the Chaixmeca microthermometry apparatus. Bull. Soc. fr. Minéral. Cristallogr., 99. 182-186.
Quesada, C., Florido, P., Gumiel, P., Osborne, J. (1987): Memoria del Mapa Geológico y Minero de Extremadura, E/1:300.000. Ed. Junta de Extremadura; Consejería de Industria y Energía; Dirección General de Industria, Energía y Minas.

Ramboz, C., Pichavant, M., Weisbrod A. (1982): Fluid inmiscibility in natural processes. Use and misuse of fluid incluision data. II. Interpretation of fluid inclusion data in terms of inmiscibility. Chemical Geol., 37, 29-48.

Ramboz, C., Schnapper, D., Dubessy, J. (1985): The $\mathrm{P}-\overline{\mathrm{V}}-\mathrm{T}-\mathrm{X}-\mathrm{fO}_{2}$ evolution of $\mathrm{H}_{2} \mathrm{O}-\mathrm{CO}_{2}-\mathrm{CH}_{4}$-bearing fluid in a wolframite vein: Reconstruction from fluid inclusion studies. Geochim. Comochim. Acta, 49, 205-219.

Ramboz, C. \& Charef, A. (1988): Temperature, pressure, burial history and paleohydrology of the Les Malines $\mathrm{Pb}-\mathrm{Zn}$ deposit: reconstruction from aqueous inclusions in barite. Econ. Geol., 83, 784800.

Roberts, S., Sanderson, D., Dee, S., Gumiel, P. (1991): Tectonic setting and fluid evolution of auriferous quartz veins from the La Codosera area, SW Spain. Econ. Geol., 86, 1012-1022.

Roedder, E. (1984): Fluid inclusions. Reviews in Mineralogy, 12, Mineral. Soc. America, 644 pp.

Seranne, M. \& Malavieille, J. (1993): Late orogenic extension in Mountain belts. Doc. BRGM Fr., N219.

Sibson, R.H. (1987): Earthquake rupturing as a mineralizing agent in hydrothermal systems. Geology, 15, 701-704.

- (1990): Faulting and fluid flow. In "Short Course on Fluids in Tectonically Active Regimes of the Continental Crust". B.E. Nesbitt, ed. Mineralogical Association of Canada, Vancouver, Canada, 93-129.

Spycher, N.F. \& Reed, M.H. (1989): Evolution of a Broadlands-type epithermal ore fluid along alternative P-T paths: implications for the transport and deposition of base, precious and volatile metals. Econ. Geol., 84, 328-359.

Thiéry, R., Vidal, J., Dubessy, J. (1994): Phase equilibria modelling applied to fluid incluions: Liquidvapour equilibria and calculation of the molar volume in th $\mathrm{CO}_{2}-\mathrm{CH}_{4}-\mathrm{N}_{2}$ system. Geochim. Cosmochim. Acta, 58, 1073-1082.

Welch, H. (1973) Die Systeme Xenon-Wasser bei hohen Drucken and Temperturen. Ph.D.thesis, Institute for Physical Chemistry, Karlsruhe, $40 \mathrm{pp}$.

Wood, S.A., Crerar, D.A., Borsick M.P. (1987): Solubility of the assemblage pyrite-pyrrhotite-magnetite-sphalerite-galena-gold-stibnite-bismuthiniteargentite-molybdenite in $\mathrm{H}_{2} \mathrm{O}-\mathrm{NaCl}-\mathrm{CO}_{2}$ solutions from $200^{\circ} \mathrm{C}$ to $350^{\circ} \mathrm{C}$. Econ. Geol., 82, 1864-1887.

Received 15 March 1994

Accepted 23 December 1994 
